\title{
SOCIAL PROTECTION FOR WORKERS POSTED TO AND FROM SOUTH AFRICA: A CRITICAL ASSESSMENT*
}

\section{Introduction}

Given the globalised nature of work in the twenty-first century, labour and social security law issues relating to worker-posting are sure to increase in the years to come. The purpose of this note is to assess critically the social protection of workers posted abroad from a South African perspective. The contribution addresses this topic by discussing various questions. It concludes by stressing the need for the adoption of a coherent approach as far as social protection for posted workers is concerned by, inter alia, promulgating an act of parliament to regulate the social security and labour law entitlements and obligations of these workers as well as their employers. In addition, it emphasises the need for and the importance of bilateral and multilateral social security and labour agreements between South Africa and other countries, particularly those where South African companies have established themselves.

A sizeable number of South African companies (such as MTN, Vodacom, SABMiller, Sasol, Woolworths and Debonairs) have established, or are successfully establishing themselves, in African countries and beyond. ("South Africa's global companies" - http://www.southafrica.info/business/ success/globalcompanies.htm).) At the same time, foreign companies (such as BMW, Levi Strauss, Barclays Bank and Vodafone) have registered, or are in the process of registering, in South Africa at an unprecedented rate. ("Global companies in South Africa" - http://www.southafrica.info/business/ investing/globalcomps.htm)). It is true that these companies do employ locals. However, situations do arise requiring a global company to send a worker for a limited period (usually not exceeding twelve months) to carry out work in the territory of a State other than the State in which he or she normally works. This scenario is commonly known as worker-posting and does yield some benefits (including international exposure) to the (posted) workers, their employers and the economy in general. Nevertheless, if not properly regulated, worker-posting may have an undesirable effect, particularly on workers. For example, posted workers may find themselves concurrently covered (ie, at home and abroad) by social insurance schemes or not covered at all. As will be explained later, this can yield undesirable results. For example, it unnecessarily raises the costs of doing business for transnational employers. Furthermore, the period of stay for posted workers is limited and, as a result often does not lead to any entitlement to benefits.

This contribution is based on a paper delivered at the Conference of Law Teachers of Southern Africa, 13-16 July 2009, Pietermaritzburg, South Africa. 
In addition, in the labour law sphere, posted workers may fall victim to abuse as regards the basic conditions of employment (eg, relating to pay and working time).

The purpose of this paper is to assess critically the social protection of workers posted abroad from a South African perspective. According to the Asian Development Bank (ADB), "social protection" consists of policies and programmes designed to reduce poverty and vulnerability by promoting efficient labour markets, diminishing people's exposure to risks, enhancing their capacity to protect themselves against hazards and interruption/loss of income" (Asian Development Bank "Social Protection: Reducing risks, increasing opportunities" - http://www.adb.org/SocialProtection/default.asp). The aim of social protection for that reason, is to avert or minimise social risks - in that way preventing or minimising human damage - by increasing capabilities and opportunities. As noted by the UN Commission:

"The ultimate purpose of social protection is to increase capabilities and opportunities and, thereby, human development. While by its very nature social protection aims at providing at least minimum standards of well-being to people in dire circumstances enabling them to live with dignity, one should not overlook that social protection should not simply be seen as a residual policy function of assuring the welfare of the poorest - but as a foundation at a societal level for promoting social justice and social cohesion, developing human capabilities and promoting economic dynamism and creativity" (United Nations Enhancing Social Protection and Reducing Vulnerability in a Globalising World: Report of the Secretary-General (39th Session of the Commission for Social Development (2000)))

This contribution addresses this topic by discussing the following questions: What is the social protection status, with reference to social security and labour law, of workers posted to and from South Africa? Is the present social security and labour law protection framework ideal for extending social security and labour law protection to posted workers? To the extent that it is not, where and what are the gaps and challenges that are likely to hinder efforts to extend or strengthen social security and labour law coverage to this category of workers? Finally, what are the alternatives for improving, in a worker-posting context, the current social protection framework?

\section{The social security regime and posted workers}

\section{The social security framework: A synopsis}

In light of the above-mentioned globalised nature of work, the call for addressing the worker-posting challenges facing workers has never been stronger. South Africa has, viewed from a developing country's perspective, a well developed social security system. Imperfect as it is, the South African social security system, through both social assistance and social insurance schemes, caters for all the so-called nine classical risks (namely, sickness, maternity, employment injury, unemployment, invalidity, old age, death, medical care and family) contained in the International Labour Organisation Social Security (Minimum Standards) Convention 102 of 1952. It must be 
noted that apart from the social assistance and social insurance schemes currently in existence, there are private insurance schemes and informal coping strategies (also known as informal social security) that play an important role in shielding individuals and their families from a variety of social risks. This paper, however, pays particular attention to social insurance, which is the most appropriate yet problematic form of social security when viewed from a worker-posting perspective.

\section{Social security status of workers posted to and from South Africa}

\section{Personal scope of coverage}

The personal scope of coverage of various social insurance schemes of the world is typically set out in (a) contingency specific piece(s) of legislation regulating the applicable scheme(s). For example, the scope of coverage on the Namibian Maternity, Sick Leave and Death Benefit Fund, National Medical Benefit Fund, and National Pension Fund is set out in the Social Security Act 34 of 1994. This approach can also be discerned from the South African social insurance framework. Each and every social insurance scheme in South Africa is regulated by (an) act(s) of parliament. For example: (a) the Compensation for Occupational Injuries and Diseases Act 130 of 1993 (COIDA) mainly provides for compensation for disablement caused by occupational injuries or diseases sustained or contracted by employees in the course of their employment, or for death resulting from such injuries or diseases (Preamble of the COIDA); (b) the Unemployment Insurance Act 63 of 2001 (UIA) and the Unemployment Insurance Contributions Act 4 of 2002 (UICA) deal specifically with unemployment insurance in South Africa; (c) the Pension Funds Act 24 of 1956 provides mainly for the registration, incorporation, regulation and dissolution of pension funds; and (d) the primary goal of the Medical Schemes Act 131 of 1998 is to consolidate the laws relating to registered medical schemes; to provide for the establishment of the Council for Medical Schemes as a juristic person; to provide for the appointment of the Registrar of Medical Schemes; to make provision for the registration and control of certain activities of medical schemes; to protect the interests of members of medical schemes and to provide for measures for the co-ordination of medical schemes (Preamble of the Medical Schemes Act). It is these pieces of legislation that define who is, or who should be, covered by the social insurance scheme(s) which they regulate. (In this contribution, particular attention is paid to UIA, UICA and COIDA due to the fact that they mainly make provision for short term benefits. As workers are generally posted for a short duration, this makes the aforementioned pieces of social insurance legislation key to the theme under discussion.) For instance, the UIA and the UICA are not applicable to posted workers. This assertion is informed by the fact that the UIA and UICA do not apply to persons who enter South Africa for the purpose of carrying out a contract of service, apprenticeship or learnership if there is a legal or a contractual requirement or any agreement or undertaking that such persons must leave the country or that such 
persons be repatriated upon termination of the contract. Unlike the UIA and UICA, the COIDA allows an employer who carries on business chiefly outside South Africa to make arrangements with the Compensation Commissioner to cover their employees who are temporarily engaged in work in South Africa (s 23(3)(a) of COIDA).

\section{Territorial scope of coverage}

Social insurance laws spell out the territorial reach of the scheme(s) concerned (eg, whether benefits are exportable or not) and, in a majority of instances, apply within the geographical borders of the State that enacted them. The territorial scope of coverage of the South African social insurance laws vary from one piece of legislation to another. For example, the scope of application of the UIA is restricted to the territory of South Africa. In Unemployment Insurance Board v Dietriech (1968 4 SA 572 (T)), a case decided under the previous Unemployment Insurance Act, the Court held that the contributor who is unemployed by reason of illness is not entitled to an illness allowance during such period as he or she is outside the Republic of South Africa. It rejected the submission that "a person who is unemployed by reason of illness is deemed to 'capable and available for work', and that, because of the speed of modern air travel, there is no reason why a person who is unemployed by reason of illness should be deemed to be "capable of and available for work' in when he is in the Republic, and not also when he is not in the Republic" (576). COIDA, on the other hand, applies to employees who are ordinarily employed in South Africa but are employed outside the country on a temporary basis by an employer who carries on business chiefly in South Africa (s 23(1)(a) of COIDA). This is subject to the condition that the employees concerned must not be employed outside South Africa for a continuous period of more than 12 months unless the employee, employer and commissioner reach an agreement to the contrary (s 23(1)(c) of COIDA).

\section{Key challenges stemming from worker posting practice}

\section{Concurrent social insurance coverage}

There is a risk that a worker posted abroad from South Africa or posted from abroad to South Africa may be double-insured for the same contingency. The South African compensation for occupational injuries and diseases scheme provides a perfect example of this. This is, for several reasons, undesirable. Firstly, it needlessly inflates the cost of doing business for transnational employers. Furthermore, it can lead to unnecessary conflict of laws. 


\section{Lack of social insurance coverage}

Apart from the dual coverage possibility, a posted worker may find himself or herself without any social insurance cover for a particular social risk. Unemployment insurance, as provided for in South Africa, is the case in point. The likelihood of this happening is higher in a case where the host State does not have a social insurance scheme equivalent to that of the home State or vice versa. This is a reality that should not be ignored given the asymmetry that exists between most social security systems of the world. Social security systems of most developed nations are more advanced than that of a majority of developing nations which are often undeveloped or underdeveloped. Another point to be observed is that even if countries may have advanced social security systems, there are often differences in the manner in which these systems are designed, managed and financed. By way of an example, the rate of contribution, earnings ceiling, qualifying period and benefits regarding an unemployment insurance scheme may vary from one country to another. In addition, posted workers may be barred from participating in a social insurance scheme due to factors such as the following:

- The existence of a nationality requirement in the nation's social insurance legislation;

- the duration of employment or residence is too short to entitle the worker concerned to social insurance coverage; and

- coverage is made conditional on reciprocity between States (Abella Sending Workers Abroad: A Manual for Low- and Middle-Income Countries (1993) 93).

To sum up, the problem of incompatibility between social security systems is a challenge that cannot be ignored in endeavours to ensure social security coverage to posted workers.

\section{Loss of rights acquired}

Finally in this regard, workers posted abroad run a risk of losing the social security rights acquired in the host State. This risk emanates largely from the territoriality of social security rights as regards the provision of benefits. The effect of this is that if the social security legislation of the host country does not make provision for the exportability or transferability of benefits a posted worker's rights acquired through, for instance, completion of insurance or contribution periods are likely to be forfeited.

\section{Labour law framework and posted workers}

\section{Labour law framework: A brief overview}

South Africa has an elaborate labour law framework which makes provision for a variety of labour rights. For instance, the Constitution of the Republic of South Africa, 1996, enshrines the right to fair labour practices, freedom of 
association, organisational rights, and the right to engage in collective bargaining, as human rights in the Bill of Rights (s 23 of the Constitution of the Republic of South Africa). In addition, the Labour Relations Act (66 1995) makes provision for inter alia freedom of association, organisational rights, strikes and lock outs, trade unions and employers' organisation, dispute resolution, unfair dismissals and unfair labour practices. Furthermore, the Basic Conditions of Employment Act (75 of 1997) provides for, among others, the following: regulation of working time, leave, particulars of employment, termination of employment, prohibition of employment of children and forced labour, variation of basic conditions of employment, sectoral determinations and monitoring, enforcement and legal proceedings. The preceding labour rights are universally known and catered for in most countries of the world. As shown below, this does not necessarily mean that they are, or will always be, respected or that they are always available to all workers (including posted workers).

\section{Labour law status of workers posted to and from South Africa}

\section{Personal scope of coverage and associated worker posting challenges}

Labour laws generally apply to employees and their employers. To put it differently, a person has to be an "employee" or an "employer" as defined in the applicable labour statute to be covered. This implies that persons who do not fall within that ambit of the definition of "employee" or "employer" as contained in labour laws do not enjoy the protection provided by such laws. In South Africa, one has to be an employee or an employer to be covered by, for example the LRA and the BCEA. Both statutes define an "employee" as "any person, excluding an independent contractor, who works for another person or for the State and who receives, or is entitled to receive, any remuneration; and any other person who in any manner assists in carrying on or conducting the business of the employer" (s 213 of the LRA and s 1 of the BCEA). In some instances certain categories of employees are totally excluded from the scope of coverage of some labour laws. For example, the so-called "soldiers and spies" (members of the National Defence Force, National Intelligence Agency, South African Secret Service, South African National Academy of Intelligence and Comsec (which deals with communications security)) are excluded from the ambit of, for instance, the LRA and BCEA ( 2 of the LRA and $s 3$ of the BCEA). Furthermore there are categories and groups of persons who are partially covered by some labour laws in the sense that they are excluded from the operation of certain provisions. For example, in South Africa, senior managerial employees, employees engaged as sales personnel who travel to the premises of the customers and who regulate their own working conditions and employees who work fewer than 24 hours for an employer are excluded from most provisions of Chapter II of the BCEA (these provisions include $s 8$ 
(interpretation of day), s 9 (ordinary hours of work), s 10 (overtime), s 14 (meal intervals) and s 16 (pay for work on Sundays) of the BCEA).

\section{Territorial scope of coverage and worker posting related problems}

Labour laws are largely territorial in nature. This is mainly due to the principle of sovereignty (Parry v Astral Operations Ltd [2005] 10 BLLR 989 (LC) par 51). The implication of this is that labour legislation, in the majority of instances, applies only to persons employed in the territory of the country that enacted such law. South Africa is a case in point. The territorial limitations of labour law can give rise to a variety of worker posting (related) difficulties. Firstly, the territorial limitations of labour law could lead to disputes over territorial jurisdiction (see Astral Operations Ltd v Parry (2008) 29 ILJ 2668 (LAC); August Läpple (South Africa) v Jarrett [2003] 12 BLLR 1194 (LC); Kleynhans v Parmalat [2002] 9 BLLR 879 (LC); Pearson v Sheerbonnet SA (Pty) Ltd (1999) 20 ILJ 1580 (LC); and Roodt "Jurisdiction of the South African Labour Court: Employer Identity and Party Autonomy" 200315 SA Merc LJ 135). Secondly, the enforcement and monitoring of labour rights may pose a serious challenge. By way of an example, "[t]he inspectors of the Department of Labour cannot cross the borders into a neighbouring state and enforce South Africa's safety regulations, child labour protections or minimum wage determinations" (Parry v Astral Operations Ltd supra par 51). Furthermore, the Labour Court, in some cases, lacks jurisdiction to enforce orders against foreign states (see Nobela $v$ Consulate General USA [1999] 1 BLLR 31 (LC); and DeGeorges and Safari Club International (2002) 23 ILJ 952 (CCMA)).

\section{Options for addressing the worker-posting challenges: A social security and labour law perspective}

\section{General observations}

As shown above, the manner in which worker-posting is regulated in South Africa is deficient and, in some instances, incoherent. The issue requires urgent redress. The following non-exhaustive multilateral, bilateral and unilateral options may be considered in attempts to remedy the social security and labour law worker-posting challenges outlined above.

\section{Multilateral level (International Labour Organisation's Conventions)}

This option involves the ratification and appropriate implementation (accompanied by effective monitoring and enforcement of these standards) of applicable social security and labour conventions of the International Labour Organisation. This should include the so-called up-date conventions in the field of social security and the ratification of the fundamental human 
rights conventions. The "up-date conventions" include the Social Security (Minimum Standards) Convention 102 of 1952, the Medical Care and Sickness Benefits Convention 130 of 1969, the Employment Promotion and Protection against Unemployment Convention 168 of 1988, the Invalidity, Old-Age and Survivors' Benefits Convention 128 of 1967, the Employment Injury Benefits Convention 121 of 1964, the Maternity Protection Convention 183 of 2000, the Equality of Treatment (Social Security) Convention 118 of 1962, and the Maintenance of Social Security Rights Convention 157 of 1982 (the last two mentioned Conventions require Member States to negotiate in good faith with other ratifying countries in order to conclude social security agreements). The effect of such a classification is that new social security international standards now must take the content of the eight current Conventions into account before they are adopted (see, ILO "International labour standards by subject" - http://www.ilo.org; Kulke "Overview of Up-to-date ILO Social Security Conventions" in Pennings (ed) Between Soft and Hard Law: The Impact of International Social Security Standards on National Social Security Law (2006) 27; and Javillier "The Impact of International Social Security Standards" Conference on the ISSA Initiative, Vancouver, Canada, 10-12 September 2002). The fundamental human rights conventions refer to Conventions 87 and 98 (freedom of association and collective bargaining), Conventions 29 and 105 (elimination of forced and compulsory labour), Convention 100 and 111 (elimination of discrimination in respect of employment and occupation) and Conventions 138 and 182 (abolition of child labour). While it is commendable that South Africa has ratified all the fundamental human rights conventions of the ILO, it is unfortunate that (as on 17 August 2009) it has not ratified any of the up-todate social security instruments. It is therefore recommended that South Africa ratify and implement the up-to-date social security conventions as a matter of urgency. This recommendation should be understood from the context that South Africa is a member of the ILO. By virtue of such membership, it should strive at ensuring that its social security system dovetails with international social security standards and, most importantly, echoes the ethos and aspirations of the ILO.

\section{Bilateral level (Bilateral agreements)}

Bilateral agreements between South Africa and States in which South African companies have established themselves can play a meaningful role in alleviating some of the worker-posting challenges alluded to above. These labour and social security agreements could contain provisions relating to, among others, the following:

(a) Social security: Non-discrimination, equality of treatment between nationals and non-nationals, reciprocity between the home State and the host State, exportability of benefits, aggregation of the insurance periods, maintenance of the acquired rights, applicable law, contingencies to be covered, nature of the benefits to provided and rate of cash benefits. 
(b) Labour law: Maximum work periods and minimum rest periods; minimum rates of pay; health, safety and hygiene at work, equality of treatment, termination of employment and jurisdiction (whether judicial proceedings will be instituted in the host or home State).

It is disappointing to report that at bilateral level the few known (social security) agreements that South Africa have entered into have not yielded any satisfactory results to date. The labour agreements entered into by South Africa and its neighbours, for example, are the case in point. These agreements often made provision for the awarding of compensation for occupational injuries and diseases. Article XXII of the Agreement between the Government of the Republic of South Africa and the Government of the Republic of Portugal made provision for remittance of workers' compensation to the Mozambican government, which would in turn pay the worker concerned. This arrangement has over the years proved to be flawed (Mpedi "Introduction" in Becker and Olivier (eds) Access to Social Security for Non-citizens and Informal Sector Workers: An International, South African and German Perspective (2008) 9). In Mozambique, for example, it has been reported that workers often went without receiving their workers' compensation despite the remittal of the funds. Furthermore, there are instances in which the amounts paid to workers were in some cases lower than those remitted. Apart from the foregoing, a variety of other difficulties in obtaining compensation for migrants have been documented. These problems include: delayed payments, difficulties in establishing a causal link between an injury or illness and a worker's employment and difficulty in determining how benefits are calculated (see Fultz and Pieris The Social Protection of Migrant Workers in South Africa (1997)).

\section{Unilateral level}

At a unilateral level the following options could be considered:

(a) Extra-territorialisation of social insurance laws: The South African social insurance laws should be amended so as to extend social security coverage against risks such as sickness, maternity, invalidity, old age, employment injury and occupational diseases in respect of South African workers posted abroad. Accordingly, South African social insurance laws would operate without reference to the lex loci laboris (legislation of the place of employment). The following practical problems will have to be addressed, namely: "collecting contributions from employers, when national legislation is enforceable only within the national territory" (Abella 98) and "collecting contributions from workers, other than advance payment, while they are employed abroad" (Abella 98).

(b) Developing social insurance measures for posted workers: South Africa could develop special schemes (eg, supplementary insurance) or introduce voluntary insurance for posted workers. The likely challenge with voluntary insurance is that workers may end up contributing towards such a scheme on their own without the support of their employers.

(c) Legislating an Act properly regulating the issues pertaining to posting of workers: An act of parliament dealing specifically with the social security 
and labour rights and obligations of workers and their employers could be passed. This act could also provide for the production of a certificate of coverage in the case of workers covered at the home State to avoid dual coverage. (In other words, workers should be required to prove that they are covered under the South African or foreign social security system. The certificate of coverage, which is normally issued by the country that will continue to cover a posted worker, fulfils that role. Such employees are therefore exempted from paying social security contributions in countries to which they are posted.) The enactment of such legislation does not imply complete duplication of what is already in existence. Relevant labour standards could, however, be lifted from the various labour laws (eg, basic conditions of employment can be lifted from the Basic Conditions of Employment Act) and be incorporated into the proposed legislation.

\section{Conclusion}

Given the globalised nature of work in the twenty-first century, labour and social security law issues relating to worker-posting are sure to increase in the years to come. South Africans enjoy relatively open access to countries of the Southern African Development Community and the African Union and it is necessary to examine the areas of concern, highlighted above, which accompany such mobility.

In the circumstances, this paper has stressed the need for the adoption of a coherent approach as far as social protection for posted workers is concerned by inter alia promulgating an act of parliament to regulate the social security and labour law entitlements and obligations of these workers as well as their employers. In addition, it emphasised the need for and the importance of bilateral and multilateral social security and labour agreements between South Africa and other countries, particularly those where South African companies have established themselves.

Letlhokwa George Mpedi University of Johannesburg and

Avinash Govindjee Nelson Mandela Metropolitan University, Port Elizabeth 